\title{
Can E-Commerce Provide a Solution to the Coffee Paradox?
}

\author{
The Case of Costa Rica
}

\author{
Francisco J. Mata ${ }^{1}$, Ariella Quesada ${ }^{1}$, Gabriela Mata-Marín ${ }^{2}$ \\ ${ }^{1}$ Programa de Investigación y Extensión en Tecnología de Información y Desarrollo, Escuela de \\ Informática, Universidad Nacional, Heredia, Costa Rica \\ (fmata, ariella.quesada.rosales) @una.cr \\ ${ }^{2}$ Escuela de Planificación y Promoción Social, Universidad Nacional, Heredia, Costa Rica \\ (gabymata@gmail.com)
}

\begin{abstract}
In spite of the boom in coffee consumption worldwide, farmers in coffee-producing countries are subject to increasingly lower prices. This situation is referred to as the "coffee paradox", and affects the livelihood of millions of coffee farmers and their associated workers. ICT may provide a way to address this problem by eliminating intermediaries in the global value chain for coffee; therefore, we study the effect of e-commerce systems used in Costa Rica for trading coffee on prices received by local actors and discuss whether these systems provide a solution to the coffee paradox. Based on this discussion, we propose a new e-commerce system.
\end{abstract}

Keywords: ICT and sustainable economic development $\cdot$ E-commerce $\cdot$ Coffee - Costa Rica

\section{Introduction}

Coffee is the most widely traded tropical agricultural product in the world and approximately 70 countries in the world produce coffee [1]. It is estimated that 25 million farmers -mainly smallholders- produce $80 \%$ of the coffee in the world, and that this agricultural product provides a livelihood to another 100 million people [2,3]. Therefore, coffee prices are essential for improving living conditions, particularly in low-income producing countries. Deininger and Okidi [4] estimated that a 10 percent increase in the price of exported coffee would reduce poverty by 6 percentage points in the case of Uganda.

Furthermore, global consumption of this product, estimated at 1.6 billion coffee cups every day, has doubled in the past 40 years [2] -making the global coffee market worth more than US\$70 billion in 2011 [5]. In spite of the increase in the global demand for coffee, this product has been performing as a primary commodity with declining prices due to increases in world production. This situation is referred to as the coffee paradox -i.e., "the coexistence of a 'coffee boom' in consuming countries and of a 'coffee crisis' in producing countries" [6, p. xvi]. The structure of the global

adfa, p. 1, 2011.

(C) Springer-Verlag Berlin Heidelberg 2011 
value chain (GVC) for coffee and the relative power of some of the actors involved in it -particularly intermediaries located in developed countries-are greatly responsible for this outcome.

Since e-commerce can restructure GVCs [7, 8], we analyze whether e-commerce can be used to address the coffee paradox by eliminating intermediaries. Our discussion focuses on Costa Rica, a country where we were able to obtain data and where ecommerce is actually used to trade coffee.

Although there is evidence that the e-commerce systems used in Costa Rica to trade coffee are capable of increasing earnings for local actors -due to eliminating intermediaries-, they also present limitations for effectively addressing the coffee paradox. Therefore, we argue that a new e-commerce system would be needed for this purpose.

This article is organized in five sections. Section 2 presents the major actors involved in the GVC for coffee, and explain their production and market functions, and their ability to appropriate rents. The e-commerce systems used to trade coffee in Costa Rica are presented in the section 3. Section 4 analyzes these systems and discusses their ability to solve the coffee paradox. Conclusions and recommendations are provided in the last section.

\section{Coffee Production, Processing and Distribution}

\subsection{Global Value Chain for Coffee}

As Figure 1 shows seven major actors can be identified in the global value chain (GVC) for coffee: farmers, processors, export agents, global traders, roasters, retailers, and consumers. This value chain can be divided into two components: one corresponding to actors located in developing countries and the other in developed countries.

Coffee farmers grow coffee trees that produce coffee cherries. The two main species of coffee trees are Arabica (Coffea arabica), which is the most highly regarded in terms of taste -and hence the more valued-, and Robusta (Coffea canephora), which is more resistant to diseases and pests, yet has a bitter taste and more caffeine content.

Coffee cherries are usually picked by hand by seasonal workers -in a laborintensive process- to select only the ripe cherries. After the coffee cherries are harvested, they need to be processed to separate the beans from the skin and pulp of the cherries and reduce the humidity in the beans. This process produces "green coffee" and is done in curing plants or mills. Since small farmers -who are the majority worldwide- do not have such facilities, they sell their harvested cherries to coffee processing plants -owned by independent processors- or organize into cooperatives to share processing facilities, and obtain economies of scale. 


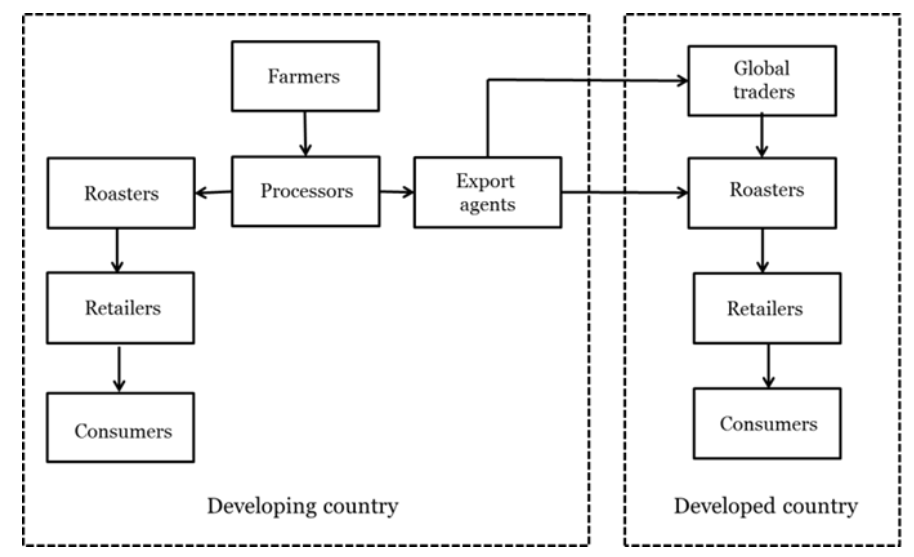

Fig. 1. GVC for Coffee (Adapted from Fitter and Kaplinsky [9] and UNCTAD [10])

Not all the coffee produced is exported; a part remains in the country for local consumption (see left-hand side of Figure 1). Thirty percent of the coffee produced was consumed internally in coffee-producing countries for the 2012-2013 coffee crop; however, most coffee-producing countries have a small local market for coffee, with the exception of Brazil, Indonesia, Mexico and Ethiopia [1]. Locally-consumed coffee is roasted by local companies and later sold to consumers in the same country mainly through local supermarkets.

On the other hand, green-coffee beans have been traditionally the main object of export for coffee-producing countries. Green-coffee is sold through export agents to global traders or directly to roasters in consuming countries.

Roasters usually first blend different types of green-coffee beans. Roasting these beans is later performed to release their aroma. Most roasted coffee is ground by the roasters and packed in vacuum-sealed bags. However, some customers prefer to buy the whole beans once roasted and ground them before brewing.

Retailers, mainly supermarkets, sell roasted ground or whole coffee, instant or soluble coffee and decaffeinated coffee to customers. Restaurants, caterers and coffee shops are other possible coffee retailers.

\subsection{Market Functions of the Intermediaries in the GVC for Coffee}

As the GVC for coffee shows (see Figure 1), there are five major intermediaries between farmers in developing countries and consumers in developed countries. In addition to the operational capacities required for coffee production, processing and distribution -already presented-, these actors also carry out market functions -that is, activities needed to facilitate the transactions in the GVC for coffee. Table 1 presents the market functions associated to each of these five intermediaries.

The previous functions reflect activities that small farmers are not capable to perform, due to lack of economies of scale, expertise, or contact networks. They are grouped in three main categories: matching buyers and sellers, facilitation of transac- 
tions, and institutional infrastructure, following the framework presented by Bakos [11].

Table 1. Market functions of the intermediaries in the GVC for coffee

\begin{tabular}{|c|c|c|c|}
\hline \multirow[b]{2}{*}{ Intermediary } & \multicolumn{3}{|c|}{ Market functions $^{\mathrm{a}}$} \\
\hline & $\begin{array}{c}\text { Matching buyers and } \\
\text { sellers }\end{array}$ & $\begin{array}{c}\text { Facilitation of } \\
\text { transactions }\end{array}$ & $\begin{array}{c}\text { Institutional } \\
\text { Infrastructure }\end{array}$ \\
\hline Processors $^{\mathrm{b}}$ & $\begin{array}{l}\text { Determination of green } \\
\text { coffee offerings }\end{array}$ & $\begin{array}{l}\text { Logistics (collecting } \\
\text { coffee cherries from } \\
\text { farmers and packaging } \\
\text { green coffee for ex- } \\
\text { port) } \\
\text { Settlement (paying to } \\
\text { famers based on crop } \\
\text { prices) } \\
\text { Trust (guaranteeing } \\
\text { quality) }\end{array}$ & $\begin{array}{l}\text { Regulatory (enforcing } \\
\text { national export regula- } \\
\text { tions) }\end{array}$ \\
\hline Export agents ${ }^{b}$ & $\begin{array}{l}\text { Search (matching coffee } \\
\text { produced with preferences } \\
\text { of global traders and inter- } \\
\text { national roasters) } \\
\text { Price discovery (deter- } \\
\text { mining price for green } \\
\text { coffee with global traders } \\
\text { and international roasters) }\end{array}$ & $\begin{array}{l}\text { Logistics (shipping } \\
\text { green coffee to traders } \\
\text { and roasters) } \\
\text { Settlement (collecting } \\
\text { payments from exports } \\
\text { and paying to proces- } \\
\text { sors) } \\
\text { Trust (guaranteeing } \\
\text { quality) }\end{array}$ & $\begin{array}{l}\text { Legal (making and } \\
\text { executing contracts } \\
\text { according to regula- } \\
\text { tions) } \\
\text { Regulatory (enforcing } \\
\text { national and interna- } \\
\text { tional regulations for } \\
\text { exporting green coffee) }\end{array}$ \\
\hline Global traders & $\begin{array}{l}\text { Search (matching coffee } \\
\text { produced with preferences } \\
\text { of international roasters) } \\
\text { Price discovery (deter- } \\
\text { mining price of green } \\
\text { coffee with international } \\
\text { roasters) }\end{array}$ & $\begin{array}{l}\text { Logistics (storing } \\
\text { green coffee in interna- } \\
\text { tional harbors and later } \\
\text { shipping it to roasters) } \\
\text { Trust (guaranteeing } \\
\text { quality) }\end{array}$ & $\begin{array}{l}\text { Regulatory (enforcing } \\
\text { international regula- } \\
\text { tions for trading green } \\
\text { coffee) }\end{array}$ \\
\hline $\begin{array}{l}\text { International } \\
\text { roasters }\end{array}$ & $\begin{array}{l}\text { Determination of roast- } \\
\text { ed coffee offerings }\end{array}$ & $\begin{array}{l}\text { Trust (guaranteeing } \\
\text { quality) }\end{array}$ & \\
\hline Retailers & $\begin{array}{l}\text { Price discovery (deter- } \\
\text { mining price of roasted } \\
\text { coffee with consumers) }\end{array}$ & $\begin{array}{l}\text { Logistics (distributing } \\
\text { roasted coffee or } \\
\text { coffee drinks to con- } \\
\text { sumers) }\end{array}$ & \\
\hline
\end{tabular}

a. Based on the framework for market functions proposed by Bakos [11]

b. Activities of processors and export traders are regulated by law in Costa Rica

Auctioning and negotiation are used as price discovery mechanisms for green coffee, whereas fixed pricing is used for roasted coffee. This is due to the larger volume 
traded in green coffee between companies, in comparison to the small quantity of roasted coffee bought by consumers.

Furthermore, guaranteeing the quality of coffee is an important market activity for several of the intermediaries in the GVC for coffee, as Table 1 shows. This is due to the fact that coffee is an experience good, rather than a search good. An experience good is one for which its quality and price can only be assessed after consumption, as opposed to a search good whose characteristics can be fully determined before purchase [12]. Quality considerations for coffee are further elaborated.

\subsection{Coffee and Quality}

To understand the impact of e-commerce on the GVC for coffee and its possible uses for addressing the coffee paradox, we need to distinguish between mainstream and specialty coffee. These two types of coffee are discussed below.

Mainstream coffee is intended for the general public and represents between 80$90 \%$ of the total coffee market [13]. Mainstream coffee is considered an agricultural commodity, which is traded following the traditional GVC for coffee: coffeeproducing countries export green coffee, which is later roasted and sold in developed countries (see Figure 1). Essential in this GVC is the undifferentiated (commodity) nature of coffee for consumers. This allows international roasters to rely on different types of coffee beans to produce the blends associated to their own brands. Since taste differences are difficult to detect by most coffee drinkers, this practice makes it possible for these roasters to substitute beans based on prevailing economic conditions - obtaining higher profitable positions than other actors in the GVC for coffee [14].

On the other hand, specialty coffee can obtain $25 \%$ or more in price premiums at the retail level, although this type of coffee only represents $10-15 \%$ of total coffee traded [13]. The emergence of the specialty coffee market is an attempt to differentiate coffee and promote decommodification [6], [9], [14], [15]. This type of coffee is less related to traditional or common industrial blends (i.e., mainstream coffee), and more to high quality and/or limited availability on the supply side (gourmet or eco/sustainable coffee), or flavoring and ambience on the demand side [6], [13].

Decommodification in the specialty coffee market allows upgrading in the GVC for coffee. Upgrading is the process by which a firm improves its economic position in a GVC [16]. In this regard, four upgrading opportunities are possible for coffee: (i) process upgrading -aimed at increasing efficiency in the production process, for example through eco/sustainable certifications-, (ii) product upgrading -that is, producing more sophisticated products with higher value-added, such as organic coffee or coffee with geographical indication-, (iii) functional upgrading - which involves adopting new functions or abandoning old ones with the aim of increasing the skill content, for example when farmers sell directly green coffee to roasters in developed countries-, and (iv) intersectoral upgrading -that is, applying competences acquired in a certain value chain to a different sector or another chain, such as the case when roasters in coffee-producing countries use competences acquired in blending and roasting high quality coffee to sell roasted coffee directly in the international market 
[14]. Functional and intersectoral upgrading are epitomized in the e-commerce systems used in Costa Rica to trade coffee, as explained in section 3.

\subsection{Rent Appropriation}

One of the main controversies in coffee, as well as in other tropical agricultural products, is the distribution of rents between developing and developed countries [2], [6], [9], [14], [15]. Each of the activities described in the GVC for coffee add value to the product purchased by the final consumers, and therefore is reflected in the final price. However, it is commonly observed that a hierarchy of value exists in GVCs, with less wealth appropriated in nodes associated to the production of raw materials, usually located in poor or developing countries. Wealth increasingly grows as activities advance to manufacturing and distribution, commonly located in rich or developed countries [17].

Furthermore, under oligopolistic conditions some actors may be able to extract rents -i.e., a compensation beyond their value-added. These oligopolistic conditions are present in the GVC for coffee, since four multinational corporations control $45 \%$ of the roasting segment [3]. These numbers contrast with the 25 million persons involved in coffee production -mainly smallholder farmers, who account for $80 \%$ of the total coffee production [2].

The previous condition favors an asymmetrical distribution of income between developing and developed countries, in which on average $30 \%$ of the retail price of coffee is shared by developing-country actors whereas $70 \%$ by developed-country players [6], [15]. In particular, farmers in developing countries are able to receive just 7 $10 \%$ of the retail price of the coffee sold in developed countries [13].

Although most coffee for household consumption is purchased worldwide in supermarkets for a matter of convenience, it is not these retailers -but roasters- that enjoy a privileged position in the GVC for coffee. This situation differs from other agricultural products, for example fruit and vegetables, for which supermarkets establish quality standards and impose logistical requirements [6]. Therefore, the governance of the GVC for coffee -reflecting authority and power relationships among actors in the chain [17]- rests on international roasters, particularly those that are multinational.

\section{E-Commerce Systems for Coffee in Costa Rica}

The two e-commerce systems used to trade coffee in Costa Rica are presented in this section, according to the type of coffee they focus on: green or roasted.

\subsection{E-Commerce Systems for Green Coffee}

As indicated before, the majority of exports of coffee from producing countries are in the form of green coffee. The need for roasters to know in advance the quality of this type of coffee before buying explains why pioneering digital exchanges for main- 
stream green coffee have failed (for an explanation of these exchanges see [10], [13], [18]), leaving only futures-markets systems to protect prices. The lack of success to establish internationally-agreed standards for green coffee favors international roasters to buy such coffee from known export agents and global traders to reduce quality risk, as presented in Figure 1.

To solve the previous problem, the Cup of Excellence (CofE) $)^{1}$ scores the quality of green coffee before it is traded through an auctioning system. This business-tobusiness (B2B) system is used by farmers to directly sell specialty green coffee to roasters in developed countries. The system is aimed at rewarding quality, considering the organoleptic characteristics of the coffee traded, and promotes national competitions for gourmet coffee in several countries, including Costa Rica. Organoleptic characteristics are associated to the human senses, and in the case of coffee they are related to acidity, aroma, body and flavor [6], [15]. Combinations of these attributes are considered in coffee cupping (see [13] for more information).

Farmers interested in participating in the CofE may submit a sample of green coffee. To produce this coffee, farmers process their own coffee cherries to obtain a small lot of green coffee -referred to as a micro-lot- not requiring a processor in this case, although they may use the facilities of an existing processor.

These micro-lots are scored before an Internet auction, based on several cupping rounds, first conducted by a national jury and later by an international jury. These contests serve as the basis for selecting samples to be auctioned on the Internet. Samples of the coffees selected can be requested by potential buyers for their independent cupping, before the auction. Providing samples is a way to reduce information asymmetry regarding quality [19]. Therefore, these ex-ante mechanisms (cupping contests and samples) solve the quality problems previously noted for trading green coffee through e-commerce in the mainstream market.

The CofE enables farmers to sell directly to roasters in developed countries. In this way traditional processors, export agents and global traders in the GVC for coffee are disintermediated (see Figure 2). In doing so, however, the Asociación de Cafés Finos de Costa Rica -organizer of the Cup of Excellence in Costa Rica- acts as export agent for the coffees traded in the auction. ${ }^{2}$

Figure 3 presents the highest and weighted average prices obtained by the coffee auctioned in Costa Rica through the CofE since 2007 and compares them with the corresponding ICE Futures Market price. Overall, difference in prices between the highest bids obtained in these auctions and the futures market prices range from $660 \%$ (2011) to $3,215 \%$ (2015) and vary from $-1 \%$ (2011) to $552 \%$ (2013) between the weighted average bids and this same benchmark price.

\footnotetext{
${ }^{1}$ This is a program developed by the Alliance for Coffee Excellence, a US-based non-profit organization. See http://www.allianceforcoffeeexcellence.org for more information.

${ }^{2}$ By law, green coffee in Costa Rica can only be exported by a registered export agent.
} 


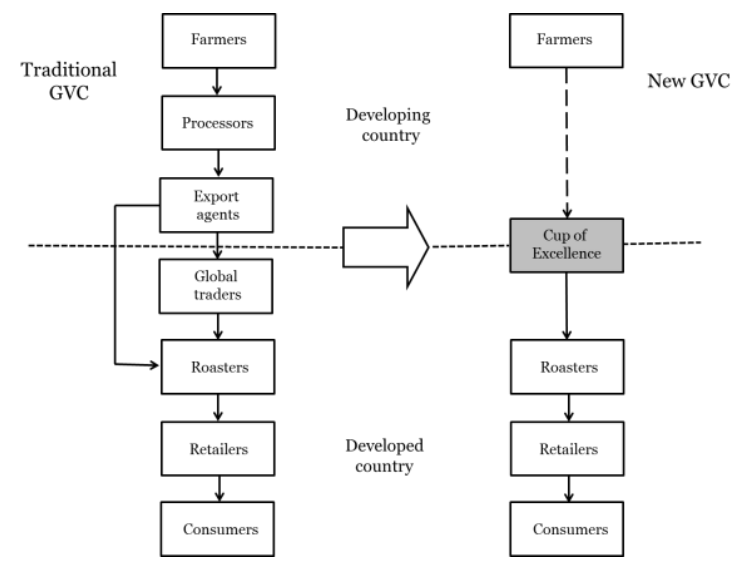

Fig. 2. Traditional GVC for Coffee and its transformation by the CofE

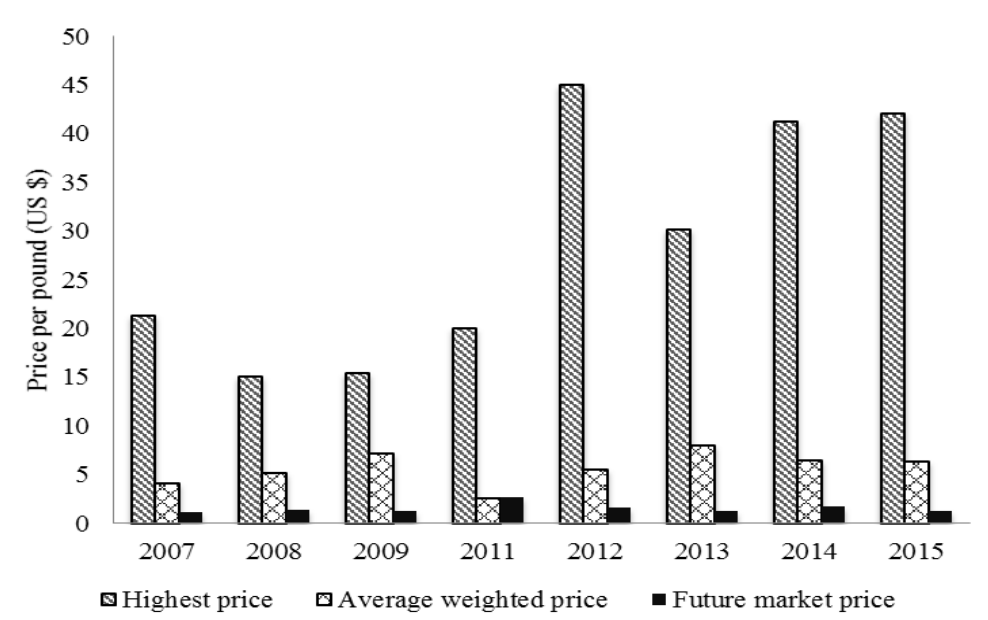

Notes: The CofE was not organized in Costa Rica in 2010.

Source: https://www.allianceforcoffeeexcellence.org/en/cup-of-excellence/auction-results/ (CofE prices) and https://www.theice.com/FuturesUSReportCenter.shtml (ICE Futures Market prices for coffee), both retrieved on 15 January 2016

Fig. 3. Highest and average prices for coffees auctioned by the CofE in Costa Rica and comparison with ICE futures market prices

It is important to highlight that the amount of coffee traded through the CofE tends to be low in comparison with the amount of Costa Rican coffee exported. The lowest amount traded through this system was 62,199 pounds in 2009 and the highest 95,266 pounds in 2011 . In $2015,87,774$ pounds were traded, ${ }^{3}$ which is less than $0.1 \%$ of the

\footnotetext{
${ }^{3}$ Volume data for CofE obtained from http://www.allianceforcoffeeexcellence.org/en/cup-ofexcellence/auction-results/ (retrieved on 15 January 2016).
} 
total coffee exports for Costa Rica for the 2014-2015 crop. $^{4}$ This situation is due to the need to taste and score the coffee before auctioning it electronically, which limits the number of contestants, and the fact that only micro-lots of exceptional quality participate in the auction.

\subsection{E-Commerce Systems for Roasted Coffee}

Exports of roasted coffee by producing countries are very small, as previously mentioned. However, exports for this type of coffee are likely to increase since such exports carry a higher price than exports of green coffee, due to their increased addedvalue. Furthermore, higher margins can be obtained if roasted coffee is exported directly to customers [20].

For this reason, exporting roasted coffee through e-commerce is an important avenue for coffee-producing countries. This is evident in the case of Costa Rica, where 14 out of the 63 Costa Rican roasters ${ }^{5}$-that is $22 \%$ of the local roasters in the country- sell coffee through their own business-to-consumer (B2C) e-commerce sites. ${ }^{6}$ At first glance, it might be assumed that such systems are aimed to sell roasted coffee locally. However, the fact that the majority of these systems are in English confirm the fact that they are oriented to international customers.

Albeit many of the Costa Rican brands of roasted coffee traded by e-commerce are also sold through local supermarkets, their focus on geographical indication and/or eco/sustainable labeling and their emphasis on high-quality Arabica blends provides evidence that most of them correspond to specialty -rather than to mainstream- coffee. It should be noted that quality of roasted coffee is assessed by the consumers mainly through symbolic quality attributes - different from the previous e-commerce system relying on the organoleptic characteristics of the green coffee traded. Symbolic attributes are based on reputational characteristics, and in the case of coffee are reflected in brands, geographical indications, and eco/sustainable labels [6].

Figure 4 depicts the modification in the GVC due to this upgrading strategy, which changes the territoriality of the roasting function from developed countries to the coffee-producing countries. As shown in this figure, Costa Rican roasters can compete with roasters in the developed countries and also disintermediate retailers in these countries, by using this type of B2C systems.

Table 2 shows examples of the differences in price obtained by Costa Rican roasters using e-commerce by depicting some of the brands sold simultaneously in Costa Rican supermarkets and in the roasters' e-commerce system. An increase in prices, although not as notorious as in the case of the CofE, can also be observed in this ta-

\footnotetext{
${ }^{4}$ Total coffee exports for Costa Rica for the 2014-2015 crop obtained from http://www.icafe.cr/wpcontent/uploads/informacion_mercado/informes_actividad/actual/Anexos\%20Mundial.xlsx (retrieved 24 January 2016).

5 Similarly, to the case of export agents, local roasters need to be registered in Costa Rica.

${ }^{6}$ Information as of January 2016 obtained from Internet searches.
} 
ble. ${ }^{7}$ It should be pointed out that roasted coffee - different from green coffee - is not subject to export regulations in Costa Rica. Therefore, Costa Rican roasters similarly to international roasters- do not need to perform any legal or regulatory functions, when exporting roasted coffee (see Table 1).

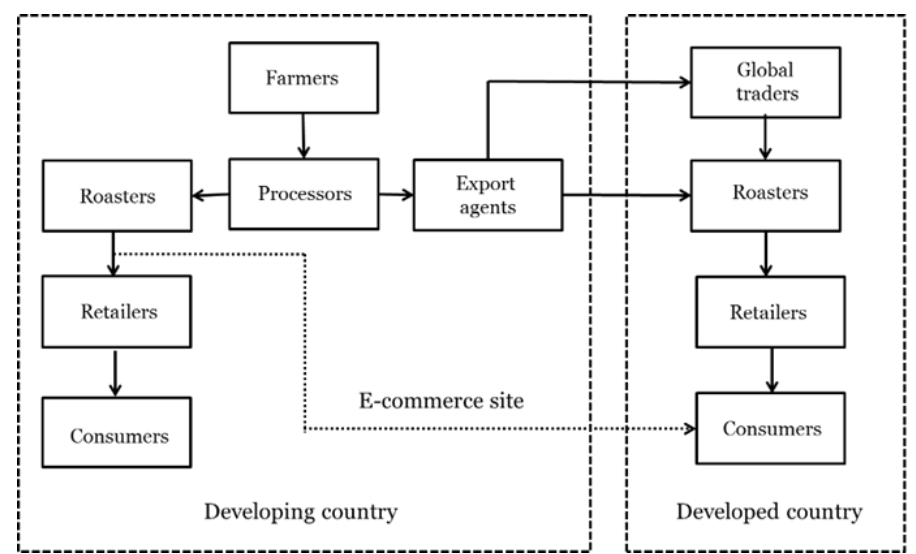

Fig. 4. Traditional GVC for coffee and upgrading achieved by e-commerce sites developed by roasters in coffee-producing countries

Table 2. Prices of roasted coffee for selected brands in US\$

\begin{tabular}{|c|c|c|c|c|c|}
\hline \multirow[t]{3}{*}{ Roaster } & \multirow[t]{3}{*}{ Brand } & \multicolumn{4}{|c|}{ Price $^{\mathrm{a}}$} \\
\hline & & \multirow{2}{*}{$\begin{array}{l}\text { EC } \\
\text { site }^{b}\end{array}$} & \multirow{2}{*}{$\begin{array}{c}\text { Super- } \\
\text { market }^{\mathrm{c}}\end{array}$} & \multicolumn{2}{|c|}{ Difference } \\
\hline & & & & Absolute & Relative \\
\hline \multirow{2}{*}{$\begin{array}{l}\text { Café Rey } \\
\text { (caferey.net) }\end{array}$} & $\begin{array}{l}\text { Rey Premium (Dark Roast } \\
\text { Ground } 400 \text { gr.) }\end{array}$ & 11.86 & 6.66 & 5.20 & $78.08 \%$ \\
\hline & Tarrazú (Ground 500 gr.) & 14.86 & 8.32 & 6.54 & $78.61 \%$ \\
\hline \multirow{3}{*}{$\begin{array}{l}\text { Grupo Britt } \\
\text { (cafebritt.com) }\end{array}$} & $\begin{array}{l}\text { Britt (Ligth/Dark Roast } \\
340 \text { gr.) }\end{array}$ & 12.95 & 8.42 & 4.53 & $53.80 \%$ \\
\hline & $\begin{array}{l}\text { Tarrazú Montecielo } \\
\text { (Ground } 340 \text { gr.) }\end{array}$ & 12.95 & 9.55 & 3.40 & $35.60 \%$ \\
\hline & $\begin{array}{l}\text { Organic Coffee (Ground } \\
340 \text { gr.) }\end{array}$ & 13.95 & 9.97 & 3.98 & $39.92 \%$ \\
\hline $\begin{array}{l}\text { Triángulo de oro } \\
\text { (triangulodeoro.com) }\end{array}$ & $\begin{array}{l}\text { Triangulo de Oro Premium } \\
\text { (Medium Roast Ground } \\
340 \text { gr.) }\end{array}$ & 9.99 & 5.07 & 4.92 & $97.04 \%$ \\
\hline
\end{tabular}

a. Prices as of 25 January 2016

b. Do not include shipping and handling

c. Prices in San José from a major supermarket chain

7 It is important to note that earnings for the roasters may be higher than the price differences shown in Table 2, since the supermarket price includes a markup to cover operation expenses and obtain profits. 


\section{Analysis of the E-Commerce Systems Used in Costa Rica for Coffee}

As presented in the previous section, the two types of e-commerce systems used in Costa Rica favor disintermediation in the case of specialty coffee, and allow increasing earnings for Costa Rican actors in the CGV for coffee. In the case of the CofE, the disintermediation is related to functional upgrading and focuses on the organoleptic characteristics of coffee. The ability of the CofE to provide market functions associated to processors, export agents, and international traders, such as settling payments to farmers, reducing search costs for international roasters to obtain highquality coffee, providing support for a new price discovery mechanism - direct auctioning by roasters for good quality-coffee is a better price discovery mechanism than the negotiation and future-markets contracts used for green coffee-, and delivering trusted -in terms of quality- third-party support for electronic transactions (see Table 1) favor cybermediation. Cybermediaries can be defined as new type of intermediaries providing functions for electronic markets offered by different intermediaries in traditional markets [8].

However, the extent of the benefits provided by the CofE is limited. Only a reduced number of farmers can participate in the competitions, due to need to cup and score the micro-lots. This limitation favors a search for scarcity from the roasters, which explains the very high prices paid for the coffee traded through this system, and also does not allow a "scalable development approach" [21].

Furthermore, a stakeholder analysis of the CofE has proved that roasters in developed countries are the real winners, since they are able to obtain even higher prices from selling the award-winning coffees than the respective farmers producing such coffees in the developing countries [6]. Therefore, this type of disintermediation does not change governance of the GVC -dominated by the international roasters, as previously explained.

On the other hand, through the e-commerce systems used by Costa Rican roasters to sell directly coffee to international customers, these roasters are able to bypass retailers in developed countries. This is done by conducting the market functions associated to international retailers in the GVC for coffee: price discovery based on fixed pricing and logistics associated to distributing roasted coffee to international consumers (see Table 1). Furthermore, the focus of these roasters in a niche (specialty coffee) favors them to substitute international roasters through reintermediation [8]. This is possible thanks to intersectoral upgrading using competences for speciality coffee, acquired in the local market. Costa Rican roasters have been developing specialty-coffee brands for the local market for more than thirty years. This trend began in 1983 when Grupo Britt introduced this type of coffee for the Costa Rican market [20]. Since then, other Costa Rican roasters have emulated this strategy.

Through this reintermediation and disintermediation, the Costa Rican roasters' sites are also able to generate higher -but not as extraordinary as in the case of the CofE- prices by selling coffee internationally. Although e-commerce in this case affects territoriality in the GVC -due to the fact that the roasting function moves from developed to developing countries (see Figure 4)-, this intersectoral upgrading strate- 
gy might not necessarily favor farmers - who are the most affected by the coffee paradox. In the end, local roasters may enjoy the similar privileged position as roasters in developed countries. Therefore, these systems do not either change the governance structure of the GVC for coffee.

\section{Conclusions and recommendations}

Although the two types of e-commerce systems used in Costa Rica to export coffee internationally are able to generate higher earnings for local actors in the GVC for coffee, their effect in solving the coffee paradox is limited -as already discussed in the previous section. This situation can be explained by the fact that these systems are not able to change the governance structure of this chain, which favors roasters. Farmers, on the other hand, are the actors that mostly bear the consequences of the coffee paradox.

This governance structure is a consequence of the structural conditions in the GVC for coffee that make customers closer to roasters, hardly establishing these customers a connection with farmers. In fact, currently there is no market that allows farmers and customers to relate in a direct manner since both operate in opposite sides of the GVC for coffee [22]. While farmers are the important component in the green-coffee market, roasters become the key component in the roasted-coffee market. Since customers act in the roasted-coffee market, farmers are invisible to them. Each of the two e-commerce systems presented deal with only one of such markets and none is able to connect farmers with customers.

Based on these conclusions, we hypothesize that if e-commerce were to be used to provide a direct connection between farmers in developing countries and consumers in developed countries, a better solution to the coffee paradox would be obtained.

Although at the beginning of the coffee activity in the 19th century, it was not possible to establish a connection between farmers in developing countries and consumers in developed countries, nowadays e-commerce is able to provide such association. However, for this connection to be meaningful farmers should be able to offer roasted -and not just green- coffee.

In this sense, there is evidence that some farmers in Costa Rica are vertically integrating -farmers participating in the CofE process their own coffee cherries and others are also roasting their own coffee beans, yet in small quantities. However, to effectively achieve this integration, farmers face challenges regarding their ability to perform the market functions associated to the intermediaries they are assimilating (see Table 1) -in addition to acquiring the required skills to carry the accompanying operational aspects. E-commerce might be able to assist farmers in this regard. The creation of electronic markets through e-commerce would help in matching buyers and sellers -due to IT's ability to lower search costs [11], [19], [23].

Furthermore, e-commerce could assist functions related to facilitating transactions -e.g., logistics and payments [8]. In addition, legal and regulatory requirements for exporting roasted coffee are less stringent than for green coffee, as previously explained. 
Based on the previous, we are proposing a new e-commerce system aimed at creating an electronic market -through a cibermerdiary- for selling Costa Rican roasted coffee directly from farmers to international consumers. This new system would involve combining the functional and intersectoral upgrading processes provided by the two e-commerce systems used in Costa Rica.

Since Costa Rican farmers lack the skills and expertise, as well as the technological capacities and organizational skills to develop and operate such system, discussions for developing such a system are underway between the Universidad Nacional de Costa Rica - a public higher education having the technical expertise to develop such system- and the Asociación de Cafés Finos de Costa Rica - organizer of the Cup of Excellence in Costa Rica.

Due to the quality characteristics of coffee, a key requirement for the proposed system is creating a reputation of offering high-quality coffee for the system. This is necessary to avoid cupping and scoring the coffee offered, and open the possibility of relying on non-organoleptic coffee attributes for marketing -similar to the case of the roasters' e-commerce systems. In this way, the system would be able to rent this reputation to the producers. Renting a reputation from an e-commerce system is a viable mechanism to produce reputational spill-overs to sellers in electronic markets without having them to invest on creating their own reputation [19].

Creating this reputation for the envisioned system might be achieved by allowing only winners of the CofE to participate - a quality requirement easy to verify- in this electronic market. Yet different from the CofE, this new system should not be limited to trading exceptional -but rather good-quality- coffees. In this way, the system would avoid falling into the "scarcity trap" of the CofE, and hence allow a scalable development solution to the coffee paradox.

A system like the one proposed undoubtedly raises questions regarding the farmers' capabilities to use it -i.e., access to ICT and knowledge to use these technologies-, and to whether such a system would create a benign intermediary. We are addressing such questions by implementing a prototype in collaboration with the Costa Rican farmers.

Although the proposed system would not solve the coffee paradox for all Costa $\mathrm{Ri}$ can farmers, it would assist those already recognized for producing high-quality coffee to obtain higher earnings -in this way, contributing to mitigate the effects of the coffee paradox.

\section{References}

1. ICO: Exports of all Forms of Coffee to Exporting Countries: Calendar years 2000 to 2013. London, England: International Coffee Organization (2014).

2. Fairtrade Foundation: Fairtrade and Coffee. London, England: Fairtrade Foundation (2012).

3. World Bank: World Development Report 2008: Agriculture for Development. Washington, D.C.: The World Bank (2007).

4. Deininger, K., Okidi, J.: Growth and Poverty Reduction in Uganda, 1999-2000: Panel data evidence. Development Policy Review. 21, 481-509 (2003). 
5. Geller, M., Dalal, M.: Analysis: Single-cup Coffee Sales Seen Growing. Reuters (2012). Retrieved on July 25, 2014 from http://www.reuters.com/article/2012/02/03/us-coffeeidUSTRE81203720120203.

6. Daviron, B., Ponte, S.: The Coffee Paradox: Global Markets, Commodity Trade and the Elusive Promise of Development. Zed Books, London, England (2005).

7. Chircu, A.M., Kauffman, R.: Reintermediation Strategies in Business-to-Business Electronic Commerce. International Journal of Electronic Commerce. 4, 7-42 (2000).

8. Giaglis, G.M., Klein, S., O'Keefe, R.: The Role of Intermediaries in Electronic Marketplaces: Developing a Contingency Model. Information Systems Journal. 12, 231-246 (2002).

9. Fitter, R., Kaplinsky, R.: Who Gains from Product Rents as the Coffee Market Becomes More Differentiated?: A Value-Chain Analysis. IDS Bulletin. 32, 69-82 (2001).

10. UNCTAD: Electronic Commerce and Development Report 2003. New York, NY: United Nations Conference on Trade and Development (2003).

11. Bakos, Y.: The Emerging Role of Electronic Marketplaces on the Internet. Communications of the ACM. 41, 35-42 (1998).

12. Nelson, P.: Information and Consumer Behavior. Journal of Political Economy. 78, 311329 (1970).

13. ITC: The Coffee Exporter's Guide (3rd ed.). Geneva, Switzerland: International Trade Centre (2011).

14. Kaplinsky, R., Fitter, R.: Technology and Globalisation: Who Gains when Commodities are De-commodified? International Journal of Technology and Globalisation. 1, 5-28 (2004).

15. Fitter, R., Kaplinsky, R.: Can an Agricultural 'Commodity' be De-commodified, and if so Who is to Gain? IDS Bulletin. Brighton, United Kingdom: Institute of Development Studies, University of Sussex (2001).

16. Gereffi, G., Humphrey, J., Sturgeon, T.: The Governance of Global Value Chains. Review of International Political Economy. 12, 78-104 (2005).

17. Gereffi, G., Korzeniewicz, M., Korzeniewicz R.P.: Introduction: Global Commodity Chains. In G. Gereffi, G. \& M. Korzeniewicz (Eds.), Commodity chains and global capitalism. Westport, CT: Praeger Publisher (1994).

18. UNCTAD: Electronic Commerce and Development Report 2001. New York, NY: United Nations Conference on Trade and Development (2001).

19. Choi, S., Whinston, A., Stahl, D.: The Economics of Electronic Commerce. Indianapolis, Indiana: Macmillan Computer Publishing (1997).

20. Brenes, E.R., Bolaños, I., Burciaga, R., Jimeno, M., Salas, F.: Café Britt S.A. Journal of Business Research. 38, 23-33 (1997).

21. Wilson, B.R., Conley, J.F., Harris, T.M., Lafone, F.: New terrains of Taste: Spatial Analysis of Price Premiums for Single Origin Coffees in Central America. Applied Geography. 35, 499-507 (2012).

22. Pelupessy, W.: La Crisis de Mercado en Cadenas Globales del Café. Perspectivas Rurales. 5, 57-71 (2001).

23. Bakos, Y.: The Emerging Landscape for Retail e-commerce. Journal of Economic Perspectives. 15, 69-89 (2001). 